\title{
Biological Properties of Calcium Phosphate Bioactive Glass Composite Bone Substitutes: Current Experimental Evidence
}

\author{
Maria Karadjian ${ }^{1,+}{ }^{+}$Christopher Essers ${ }^{1,+}{ }^{,}$, Stefanos Tsitlakidis ${ }^{1}$, Bruno Reible ${ }^{1}$, \\ Arash Moghaddam 1,2, Aldo R. Boccaccini ${ }^{3}$ (D) and Fabian Westhauser ${ }^{1, *(D)}$ \\ 1 Center of Orthopedics, Traumatology, and Spinal Cord Injury, Heidelberg University Hospital, Schlierbacher \\ Landstr. 200a, 69118 Heidelberg, Germany; maria.karadjian@med.uni-heidelberg.de (M.K.); \\ christopher.essers@med.uni-heidelberg.de (C.E.); stefanos.tsitlakidis@med.uni-heidelberg.de (S.T.); \\ bruno.reible@gmail.com (B.R.) \\ 2 ATORG-Aschaffenburg Trauma and Orthopedics Research Group, Center for Trauma Surgery, \\ Orthopedics, and Sports Medicine, Klinikum Aschaffenburg-Alzenau, Am Hasenkopf 1, \\ 63739 Aschaffenburg, Germany; Arash.Moghaddam-Alvandi@klinikum-ab-alz.de \\ 3 Institute of Biomaterials, University of Erlangen-Nuremberg, Cauerstr. 6, 91058 Erlangen, Germany; \\ aldo.boccaccini@ww.uni-erlangen.de \\ * Correspondence: Fabian.Westhauser@med.uni-heidelberg.de; Tel.: +49-6221-56-25000 \\ $\dagger$ These authors contributed equally to this work.
}

Received: 24 December 2018; Accepted: 9 January 2019; Published: 14 January 2019

\begin{abstract}
Standard treatment for bone defects is the biological reconstruction using autologous bone-a therapeutical approach that suffers from limitations such as the restricted amount of bone available for harvesting and the necessity for an additional intervention that is potentially followed by donor-site complications. Therefore, synthetic bone substitutes have been developed in order to reduce or even replace the usage of autologous bone as grafting material. This structured review focuses on the question whether calcium phosphates (CaPs) and bioactive glasses (BGs), both established bone substitute materials, show improved properties when combined in CaP/BG composites. It therefore summarizes the most recent experimental data in order to provide a better understanding of the biological properties in general and the osteogenic properties in particular of $\mathrm{CaP} / \mathrm{BG}$ composite bone substitute materials. As a result, BGs seem to be beneficial for the osteogenic differentiation of precursor cell populations in-vitro when added to CaPs. Furthermore, the presence of BG supports integration of CaP/BG composites into bone in-vivo and enhances bone formation under certain circumstances.
\end{abstract}

Keywords: calcium phosphate; bioactive glass; bone substitutes; composite bone substitute materials; bone tissue engineering

\section{Introduction}

Bone defect augmentation belongs to the clinically most important procedures, not only in orthopedic surgery, but also in the overall context of modern medicine: With two million procedures annually, bone grafting is the second most performed tissue transplantation in the United States after blood transfusion [1]. The current gold standard of bone defect repair remains autologous bone grafting, mostly harvested from the iliac crests [2]. This biological reconstruction of bone is described as bone tissue engineering [3]. However, defect treatment and bone tissue engineering using autologous tissue is not only restricted by the available bone substance, it also requires a second intervention that might be followed by surgical site complications [4,5]. Therefore, the development, 
evaluation and production of synthetic bone substitutes that can either limit or even replace the usage of autologous bone marrow as a grafting material is in the spotlight of experimental and clinical orthopedic research. The aim is to create synthetic bone substitutes exhibiting an intrinsic osteogenic activity and morphological features that are comparable to iliac crest bone as grafting material [6-8].

The mentioned requirements for synthetic bone substitute materials can be summarized as their "biological properties" - a term that has to be defined prior to use within this review paper. From a bone tissue engineering perspective, the term "biological properties" summarizes the influence of the respective material towards cell viability, cell proliferation, and immunogenic reaction, i.e., the biocompatibility and bioactivity [9]. However, not only biocompatibility is a requirement for bone substitutes. Specifically, their influence on osteogenic (which can be described as osteostimulation) and angiogenic differentiation, as well as osseointegration and osteoconduction are of certain importance [3,8].

In experimental settings, the biological and/or osteogenic properties of bone substitute materials are evaluated using certain in-vitro culture settings and in-vivo models. The in-vitro models mostly focus on the evaluation of cell-material contact (adherence), biocompatibility of the materials, the influence of the material itself or of soluble parts of the material on cell vitality, proliferation, and/or differentiation [10-13]. In-vivo models can either be used as bioreactors when the bone substitutes are implanted ectopically in the host organism, providing nutrition of the implant, or as actual orthotopic bone defect models $[7,14]$. Ectopic models mostly provide analysis of biocompatibility, vascularization and osteoid formation, orthotopic models also allow for analysis of (amongst others) mechanical properties, osseointegration and osteoconduction $[7,14,15]$.

The most commonly used synthetic bone substitutes to date are calcium phosphates (CaPs), mostly as derivatives of hydroxyapatite $\left(\mathrm{HA} ; \mathrm{Ca}_{10}\left(\mathrm{PO}_{4}\right)_{6}(\mathrm{OH})_{2}\right)$ and tricalcium phosphate (TCP; $\left.\mathrm{Ca}_{3}\left(\mathrm{PO}_{4}\right)_{2}\right)[8,16,17]$. Whilst the osteoconductive properties of CaPs are good, the material itself shows limited stimulation of osteogenic differentiation and surface reactivity is comparably low $[16,18,19]$. In clinical routine, CaPs suffer from the problem of either too fast or too slow resorption, again impairing biological properties: Slow resorption inhibits osseointegration, whereas fast resorption might lead to insufficient "filling" of the treated bone defect $[8,20]$.

An attractive alternative to $\mathrm{CaPs}$ as bone substitute materials are bioactive glasses (BGs): $\mathrm{BGs}$ are osteostimulative and they exhibit formation of a carbonate-substituted hydroxyapatite-like (HCA) layer on their surfaces both in-vitro and in-vivo, providing bonding to bone and surrounding tissues $[9,21]$. Furthermore, BGs are proven to stimulate angiogenic and osteogenic differentiation of stem cells by release of bioactive ions [22-24]. It is therefore possible to tailor the properties of BGs towards specific needs: For example, boron can be added to the BG composition to improve angiogenic properties [22]. The most commonly used BG is the $45 \mathrm{~S} 5$ "Bioglass" with a composition of $45 \% \mathrm{SiO}_{2}$, $24.5 \% \mathrm{Na}_{2} \mathrm{O}, 24.5 \% \mathrm{CaO}$, and $6 \% \mathrm{P}_{2} \mathrm{O}_{5}$ (in wt\%) [25]. 45S5-BG provides strong bonding to surrounding tissues and has shown osteogenic capabilities, making it a class-A-biomaterial $[25,26]$. However, 45S5-derived BGs suffer from poor mechanical properties when used as three-dimensional (3D) bone substitutes: The 45S5-BG has the tendency to crystallize during heating procedures when producing $3 \mathrm{D}$ scaffolds. As a consequence, stability decreases, making 3D scaffolds brittle [27-31]. Another limitation of the 45S5-BG, especially when used in in-vitro experimental settings, is caused by the high $\mathrm{Na}_{2} \mathrm{O}$-portion within the glass composition. In contact with (body) fluids, $\mathrm{Na}_{2} \mathrm{O}$ dissolves, causing a liberation of sodium ions followed by a strong $\mathrm{pH}$-increase that might be harmful to cells [32,33]: Whilst osteoblast function is stimulated by a slightly alkaline milieu, the osteoclast function is decreased by alkaline surroundings [34-36]. Since osteoclasts are of certain importance in the early phases of bone regeneration, the $\mathrm{pH}$-increase induced by 45S5-BG might limit the initial steps of osseous regeneration, especially when using "pure" 45S5-BG scaffolds [25,37,38]. Therefore, prior to the use of 45S5-derived BG scaffolds in in-vitro studies, pretreatment periods are necessary to diminish the initial burst release of ions resulting in a dramatic increase of $\mathrm{pH}$ [39-41]. 
There are approaches to improve the osteogenic properties and to overcome the limitations of both material types by combining CaPs and BGs creating CaP/BG composite materials. Bellucci et al. extensively reviewed the current literature concerning CaP/BG composites with a focus on material development, characteristics, and properties [16]. However, a systematic review of literature focusing on biomedical and osteogenic features of $\mathrm{CaP} / \mathrm{BG}$ composite bone substitutes is not yet available.

This structured review summarizes the most recent relevant experimental methods and data in order to provide a better understanding of the biological properties in general and the osteogenic properties of $\mathrm{CaP} / \mathrm{BG}$ composite bone substitute materials.

\section{Methods}

A structured review in the sense of a meta-analysis was conducted according to the PRISMA-guidelines by screening the PubMed database in December 2018 [42]. The MeSH Term "Calcium Phosphates" and the term "Bioglass" were applied leading to 214 results. The MeSH Term "Calcium Phosphate" summarizes the keywords "apatites", "hydroxyapatites", and "calcium phosphates", the term "Bioglass" summarizes the different bioactive glass compositions. The titles and abstracts of all results were screened according to the defined inclusion criteria: original works and biological evaluation of CaP/BG composites compared to each other or to CaP or BG respectively, designed for orthopedic application regarding osteogenic properties in-vitro and in-vivo. Exclusion criteria were: Failed matching with the inclusion criteria, (metal) implant coatings consisting of CaP/BG composites, missing full-texts and full texts not available in English language. 200 publications did not match the inclusion criteria and therefore were excluded. 14 publications were included and went into meta-analysis. Since the experimental approaches found in the studies differed significantly, meta-analysis (i.e., comparative quantification) was carried out as precisely as possible. However, direct quantification and comparison of the data found was not accurately possible.

\section{Overview}

Table 1 gives an overview of the included studies summarizing the material composition, the methods used for biological characterization of the respective materials as well as the biological outcome. 
Table 1. Studies included in the review.

\begin{tabular}{|c|c|c|c|c|c|c|c|c|c|}
\hline \multirow{2}{*}{ First Author } & \multirow{2}{*}{ Ref. } & \multirow{2}{*}{ Year } & \multicolumn{2}{|c|}{ Composite } & \multicolumn{2}{|c|}{ Percentage } & \multirow{2}{*}{ Setup } & \multirow{2}{*}{ Methods/Endpoints } & \multirow{2}{*}{ Biological Outcome } \\
\hline & & & 1st Phase & 2nd Phase & 1st Phase & 2nd Phase & & & \\
\hline \multirow[b]{2}{*}{ Barbieri } & \multirow[b]{2}{*}{ [43] } & \multirow[b]{2}{*}{2017} & $\begin{array}{c}\mathrm{HA} / \beta-\mathrm{TCP} \\
4 / 96 \\
\end{array}$ & $\mathrm{AOC}$ & 51.7 & 48.3 & \multirow[b]{2}{*}{ in-vivo } & \multirow[b]{2}{*}{ Histomorphometry } & \multirow[b]{2}{*}{$\begin{array}{l}\text { Compared to CaP/AOC rarely any formation of new bone on } \\
\text { CaP/BG composite. }\end{array}$} \\
\hline & & & $\beta-\mathrm{TCP}$ & $\begin{array}{c}45 \mathrm{~S} 5(45 \mathrm{wt} \% \\
\mathrm{SiO}_{2}, 24.5 \mathrm{wt} \% \\
\mathrm{CaO}_{2} 24.5 \mathrm{wt} \% \\
\mathrm{Na}_{2} \mathrm{O}, 6 \mathrm{wt} \% \\
\left.\mathrm{P}_{2} \mathrm{O}_{5}\right) \text {-Collagen } \\
\text { mix } \\
\end{array}$ & 61.8 & 38.2 & & & \\
\hline \multirow[t]{2}{*}{ Bellucci } & \multirow[t]{2}{*}{ [18] } & \multirow[t]{2}{*}{2017} & HA & $\begin{array}{l}\text { BG_Ca/Mix } \\
\left(47.3 \% \mathrm{SiO}_{2},\right. \\
45.6 \% \mathrm{CaO}_{1} \\
2.3 \% \mathrm{~K}_{2} \mathrm{O} \\
2.3 \% \mathrm{Na}_{2} \mathrm{O} \\
\left.2.6 \% \mathrm{P}_{2} \mathrm{O}_{5}\right)\end{array}$ & $70 / 20 / 0$ & $30 / 80 / 100$ & \multirow[t]{2}{*}{ in-vivo } & \multirow[t]{2}{*}{ X-Ray, histomorphometry } & \multirow[t]{2}{*}{$\begin{array}{l}\text { Increased osteoconductivity of pure BG scaffolds compared to } \\
\text { composites, with best results for BG_Ca/Mix. } \\
\text { Improved osteoconductivity of CaP/BG composites with increasing } \\
\text { BG content. }\end{array}$} \\
\hline & & & $45 \mathrm{~S} 5$ & / & 100 & 0 & & & \\
\hline Chen & [44] & 2017 & $\begin{array}{l}\text { Si-Sr-Zn-Mg- } \\
\text { codoped CaP }\end{array}$ & $45 \mathrm{~S} 5$ & $100 / 6.7 / 0$ & 0/93.3/100 & in-vitro & $\begin{array}{c}\text { Cell proliferation, } \\
\text { osteogenic differentiation, } \\
\text { protein expression }\end{array}$ & $\begin{array}{l}\text { Improved proliferation and differentiation of mesenchymal stem cells } \\
\text { in composite materials. }\end{array}$ \\
\hline Lopes & [45] & 2016 & $\beta-\mathrm{TCP}$ & $45 S 5$ & $100 / 95 / 92.5$ & $0 / 5 / 7.5$ & in-vitro & Cell viability, SEM & Increased cell viability and advanced attachment in $7.5 \%$-composites. \\
\hline \multirow{2}{*}{ Bellucci } & \multirow{2}{*}{ [19] } & \multirow{2}{*}{2015} & HA & BG_Ca/Mix & $20 / 70$ & $80 / 30$ & \multirow{2}{*}{ in-vitro } & \multirow{2}{*}{$\begin{array}{c}\text { Cell viability, cell } \\
\text { proliferation, cytotoxicity }\end{array}$} & \multirow{2}{*}{ Cell viability in composites equivalent to $45 \mathrm{S5} 5 \mathrm{BG}$. } \\
\hline & & & $45 \mathrm{~S} 5$ & / & 100 & 0 & & & \\
\hline \multirow[t]{2}{*}{$\mathrm{Lu}$} & \multirow[t]{2}{*}{ [46] } & \multirow[t]{2}{*}{2015} & $\begin{array}{c}\mathrm{HA} / \beta \text {-TCP } \\
(40 / 60)\end{array}$ & $\begin{array}{c}58 \mathrm{~S}\left(60 \% \mathrm{SiO}_{2}\right. \\
36 \% \mathrm{CaO}, 4 \% \\
\left.\mathrm{P}_{2} \mathrm{O}_{5}\right) \\
\end{array}$ & $\mathrm{n} / \mathrm{s}$ & $\mathrm{n} / \mathrm{s}$ & \multirow[t]{2}{*}{ in-vitro } & \multirow{2}{*}{$\begin{array}{l}\text { Cell viability, osteogenic } \\
\text { differentiation }\end{array}$} & \multirow{2}{*}{$\begin{array}{l}\text { Synergistic effect of BG and CaP on osteogenic differentiation, further } \\
\text { enhanced by BMP- } 2 \text {. }\end{array}$} \\
\hline & & & $\begin{array}{c}\mathrm{HA} / \beta-\mathrm{TCP} \\
(40 / 60)\end{array}$ & / & 100 & 0 & & & \\
\hline \multirow{4}{*}{ Bernhardt } & \multirow{4}{*}{ [47] } & \multirow{4}{*}{2013} & $\beta$-ТCP & $\begin{array}{l}\text { Na-Mg-Si-BG } \\
\text { system }\end{array}$ & 96 & 4 & & & Cell viability and number increased or equal for pure $\beta$-TCP vs. \\
\hline & & & $\begin{array}{c}\mathrm{HA} / \beta-\mathrm{TCP} \\
(60 / 40)\end{array}$ & $\mathrm{SiO}_{2}$ matrix & $\mathrm{n} / \mathrm{s}$ & $\mathrm{n} / \mathrm{s}$ & in-vitro & $\begin{array}{l}\text { Cell adhesion, osteogenic } \\
\text { differentiation, cell }\end{array}$ & $\begin{array}{l}\beta-T C P / B G \text { composites. } \\
\text { No differences in osteogenic performance (ALP activity) for pure } \\
\beta-T C P \text { vs. } \beta-\text { TCP } / \text { BG after } 28 \text { days of incubation. }\end{array}$ \\
\hline & & & HA & $\mathrm{SiO}_{2}$ matrix & 76 & 24 & & & Unless pre-incubated, $\mathrm{HA} / \beta-\mathrm{TCP} / \mathrm{BG}$ composites and HA/BG \\
\hline & & & $\beta$-ТCP & I & 100 & 0 & & & composites did reduce cell number compared to pure $\beta$-TCP. \\
\hline Bellucci & [48] & 2013 & HA & $\begin{array}{l}\mathrm{BG}_{-} \mathrm{Ca}(47.3 \% \\
\mathrm{SiO}_{2}, 45.6 \% \\
\mathrm{CaO}, 4.6 \% \\
\mathrm{Na}_{2} \mathrm{O}, 2.6 \% \\
\left.\mathrm{P}_{2} \mathrm{O}_{5}\right)\end{array}$ & $80 / 60$ & $20 / 40$ & in-vitro & $\begin{array}{l}\text { Cell adhesion, cell } \\
\text { proliferation, cell } \\
\text { viability, osteogenic } \\
\text { differentiation }\end{array}$ & $\begin{array}{l}\text { Increased osteogenic differentiation for BG_Ca composites (ALP } \\
\text { activity) vs. 45S5-BG composites. } \\
\text { Increased osteogenic differentiation with increasing BG content in } \\
\text { both composites. } \\
\text { No major differences in cell proliferation between the }\end{array}$ \\
\hline & & & & $45 \mathrm{~S} 5$ & & & & & different composites. \\
\hline
\end{tabular}


Table 1. Cont.

\begin{tabular}{|c|c|c|c|c|c|c|c|c|c|}
\hline \multirow{2}{*}{ First Author } & \multirow{2}{*}{ Ref. } & \multirow{2}{*}{ Year } & \multicolumn{2}{|c|}{ Composite } & \multicolumn{2}{|c|}{ Percentage } & \multirow{2}{*}{ Setup } & \multirow{2}{*}{ Methods/Endpoints } & \multirow{2}{*}{ Biological Outcome } \\
\hline & & & 1st Phase & 2nd Phase & 1st Phase & 2nd Phase & & & \\
\hline \multirow{2}{*}{$\begin{array}{l}\text { Cholewa- } \\
\text { Kowalska }\end{array}$} & \multirow{2}{*}{ [49] } & \multirow{2}{*}{2009} & \multirow{2}{*}{ HA } & $\begin{array}{c}\mathrm{S} 2\left(80 \% \mathrm{SiO}_{2},\right. \\
16 \% \mathrm{CaO}, 4 \% \\
\left.\mathrm{P}_{2} \mathrm{O}_{5}\right) \\
\end{array}$ & \multirow{2}{*}{$100 / 90 / 50 / 0$} & \multirow{2}{*}{$0 / 10 / 50 / 100$} & \multirow{2}{*}{ in-vitro } & \multirow{2}{*}{$\begin{array}{l}\text { Cell viability, osteogenic } \\
\text { differentiation }\end{array}$} & \multirow{2}{*}{$\begin{array}{l}\text { Osteogenic differentiation (ALP activity) significantly improved for } \\
\text { the 50:50 S2 composite. }\end{array}$} \\
\hline & & & & $\begin{array}{c}\mathrm{A} 2\left(40 \% \mathrm{SiO}_{2}\right. \\
54 \% \mathrm{CaO}, 6 \% \\
\left.\mathrm{P}_{2} \mathrm{O}_{5}\right) \\
\end{array}$ & & & & & \\
\hline Hesaraki & [50] & 2009 & $\beta$-ТСР & $\begin{array}{c}64 \% \mathrm{SiO}_{2}, 26 \% \\
\mathrm{CaO}, 5 \% \mathrm{P}_{2} \mathrm{O}_{5} \\
5 \% \mathrm{MgO}\end{array}$ & $90 / 75 / 60$ & $10 / 25 / 40$ & in-vitro & Cell viability & $\begin{array}{l}\text { Improved cell viability in composite materials, regardless of } \\
\text { BG content. }\end{array}$ \\
\hline Yu & [51] & 2009 & $\beta-\mathrm{TCP}$ & $\begin{array}{c}62.04 \mathrm{wt} \% \\
\mathrm{P}_{2} \mathrm{O}_{5}, 14.68 \\
\mathrm{wt}^{2} \% \mathrm{CaO}, 13 \\
\mathrm{wt} \% \mathrm{MgO}, \\
10.28 \mathrm{wt} \% \\
\mathrm{Na}_{2} \mathrm{O} \\
\end{array}$ & $100 / 80$ & $0 / 20$ & in-vivo & SEM, histomorphometry & $\begin{array}{l}\text { No differences in in-vivo biocompatibility between pure } \beta-\mathrm{TCP} \text { and } \\
\text { composite material. }\end{array}$ \\
\hline Kucukkol-basi & [52] & 2009 & HA & $45 \mathrm{~S} 5$ & $0 / 50 / 100$ & $100 / 50 / 0$ & in-vivo & Histomorphometry & $\begin{array}{l}\text { No major differences between the composite and both pure HA } \\
\text { and 45S5-BG. }\end{array}$ \\
\hline Cai & [51] & 2009 & $\beta$-ТCP & $\begin{array}{c}45 \mathrm{wt} \% \mathrm{P}_{2} \mathrm{O}_{5}, \\
22 \mathrm{wt} \% \mathrm{CaO} \\
25 \mathrm{wt} \% \mathrm{Na}_{2} \mathrm{O}, \\
8 \mathrm{wt} \% \mathrm{MgO} \\
\end{array}$ & $100 / 80$ & $0 / 20$ & in-vitro & SEM, cell count & $\begin{array}{l}\text { BG addition increased cell number as well as attachment and } \\
\text { distribution of cells. }\end{array}$ \\
\hline Haimi & [53] & 2009 & $\mathrm{CaP}(\mathrm{n} / \mathrm{s})$ & $\begin{array}{c}\mathrm{Na}_{2} \mathrm{O}, \mathrm{K}_{2} \mathrm{O} \\
\mathrm{MgO}, \mathrm{CaO} \\
\mathrm{B}_{2} \mathrm{O}_{3}, \mathrm{TiO}_{2} \\
\mathrm{Ca}_{2} \mathrm{PO}_{5}, \mathrm{SiO}_{2}\end{array}$ & $\mathrm{n} / \mathrm{s}$ & $\mathrm{n} / \mathrm{s}$ & in-vitro & $\begin{array}{l}\text { Cell adhesion, cell } \\
\text { viability, cell } \\
\text { proliferation, osteogenic } \\
\text { differentiation }\end{array}$ & No remarkable differences between pure BG and CaP-coated BG. \\
\hline
\end{tabular}

$\beta$-TCP: $\beta$-tricalcium phosphate, AOC: Alkylene oxide copolymer, $\mathrm{n} / \mathrm{s}$ : not specified, $\%=\mathrm{mol} \%$ unless stated otherwise, $\mathrm{wt} \%=$ percentage by weight. Methods $=$ biological methods, SEM: scanning electron microscopy, ALP: alkaline phosphatase. When glass compositions are linked to names (e.g., 45S5) the exact composition is shown when mentioned first. 


\section{The Rationale behind CaP/BG Composite Materials for Application in Bone Tissue Engineering}

Bellucci et al. published a comprehensive review about CaP/BG composites in 2016, with a main focus on the material properties [16]. They identified two main motivations for the production and application of $\mathrm{CaP} / \mathrm{BG}$ composites: firstly, the possibility to tune the dissolution and the resorption behavior of the $\mathrm{CaP}$ in order to achieve superior biological properties $[1,16,19]$. The ratio of resorption and tissue remodeling and therefore the formation of bone tissue within the biomaterial, its integration into the bone, and the replacement of the material by vital bone tissue is one of the key properties making a bone substitute "attractive" [1]. Mainly for TCP-based scaffolds, strong resorption might end in overly fast chemical and cellular degradation, leading to insufficient ingrowth of bone tissue resulting in empty defect sites that remain unconsolidated [1,54]. Secondly, by addition of BGs to CaPs as a sintering aid, the resulting composite material exhibits improved mechanical properties compared to either BGs or CaPs alone [19].

From a tissue engineering perspective, by addition of BGs to CaP-based bone substitutes the positive features of both materials might be combined, whilst the negative features could be limited in the same way [29]. For example, the initial pH-increase of "pure" 45S5-derived scaffolds can be limited by adding a certain amount of BG to CaPs, creating a CaP/BG composite scaffold material $[9,16,20,24]$.

Another attractive feature of $\mathrm{BGs}$ is the surface reactivity, which defines the bioactivity of the material $[9,26,33,55]$. Compared to CaPs, the bioactivity of BGs is higher [16,56]. A combination of both materials might thus also improve the biological properties, including stimulation of precursor cells towards osteogenic differentiation, enhanced angiogenesis and a positive influence on cell viability and proliferation $[16,55]$.

\section{CaP-Types Used as Part of the Composite and Their Influence on Biological Properties}

Within the collective of studies included into the meta-analysis, in six cases HA was used $[18,19,47-49,52]$. Also in six studies, $\beta$-tricalcium phosphate ( $\beta$-TCP) was used as the CaP-part of the composite material $[43,45,47,50,51]$. In three cases, a mix of HA and $\beta$-TCP was used: Lu et al. described that the HA/ $\beta$-TCP mix in a ratio of 40:60 serving as CaP part of the scaffolds comes closer to the physiological composition of bone and therefore exhibits improved biocompatibility [46]. In the study of Bernhardt et al., several CaP compositions were used, including pure HA and $\beta$-TCP as well as a HA / $\beta$-TCP mix with a ratio of 60:40 [47]. Interestingly, the study focused on evaluation of the osteogenic properties of materials that are already available for clinical use. Barbieri et al. used a combination of $\beta$-TCP and HA in a ratio of 96:4. However, the HA/ $\beta$-TCP mix was not combined with BG but with an alkylene oxide copolymer (AOC) [43].

$\mathrm{HA}$, a highly crystalline form of $\mathrm{CaP}$, shows excellent biocompatibility, coming very close to the inorganic extracellular mineralized phase of bone $[8,16,17]$. Mostly used as a porous scaffold material, HA exhibits osteoconductive features with limited osteostimulation together with a slower rate of resorption compared to other CaPs such as TCP [20]. HA tends to be brittle, especially with increasing porosity of scaffolds [20]. The most commonly used TCP is $\beta-\mathrm{TCP}$, showing faster resorption rates compared to HA and exhibiting better mechanical features [20]. However, the faster rate of resorption of TCP also limits the mechanical properties when implanted into bone defects: Due to the fast degradation, defects might not be filled by newly formed bone tissue and therefore remain empty causing mechanical deficits $[8,20]$. Furthermore, the bonding of surrounding tissues to CaPs is not very strong, thus the surfaces only insufficiently provide HCA formation [56]. HCA formation is directly linked to strong bonding of bone substitutes to the surrounding tissues [9,21,33]. In the study of Chen et al. Si-Sr-Zn-Mg-codoped $\mathrm{CaP}$ was used, but the exact type of $\mathrm{CaP}$ was not specified [44]. Haimi et al. also did not specify the used CaP [53]. 


\section{BG Compositions Used}

Hench and coworkers developed the first BG in the late 1960s [57]. Since then, the family of BGs grew rapidly $[24,26,57]$. BGs have been designed to provide certain biological properties: Added as a second phase to CaPs these BGs can provide features that tailor CaPs towards a specific (clinical or experimental) field of use $[10,26,57]$. A combination of CaPs and BGs in the sense of CaP/BG composite materials might therefore be a way to combine positive aspects of both materials and-from a biological perspective-to improve cell-material interaction as well as the differentiation of precursor cells towards osteogenic lineage.

45S5-BG was the most used BG type within the included studies: Five studies used 45S5-BG as the BG part of the composite material (Table 1) [43-45,48,52]. Three studies used a glass based on the BG_Ca $\left(47.3 \% \mathrm{SiO}_{2}, 45.6 \% \mathrm{CaO}, 4.6 \% \mathrm{Na}_{2} \mathrm{O}, 2.6 \% \mathrm{P}_{2} \mathrm{O}_{5}\right)[18,19,48]$. This $\mathrm{BG}$ exhibits improved mechanical properties compared to $45 \mathrm{~S} 5-\mathrm{BG}$ due to lower sintering temperatures limiting crystallization of the glassy phase during processing $[16,19,48]$.

Some studies used BGs based on phosphorous pentoxide without silica content [51]: Yu et al. described that silicon-free glasses come closer to the composition of natural bone and also provide good bioactive properties [51]. The group of Cholewa-Kowalska used BGs with either high (S2) or low (A2) silica content [49]. Their aim was to tailor the bioactivity of the glasses within the resulting composites, as lower silica content positively correlates with bioactivity [26,49].

\section{In-Vitro Evaluation Models}

Out of the total number of 14 studies that were included in the review, in-vitro approaches were used in 10 studies (71\%). Eight of 10 studies in the in-vitro setting were performed in 3D or two-dimensional (2D) "direct" culture settings [45-51,53]. The cells were either seeded directly onto scaffolds (3D culture) or incubated in physical presence of and in contact to parts of the materials (2D culture setting, Figure 1). Within the remaining studies, additional "indirect" incubation was used [19] (Figure 1), while Chen et al. were the only group using the indirect setting exclusively [44]. This approach is specified by incubation of the material and only the material in the cell culture medium for a certain amount of time, allowing the ionic or chemical components of the material to dissolve into the medium, creating a "saturated medium" [10]. The cells are then exposed to the saturated medium without being physically exposed to the actual material. Both approaches are common ways to evaluate the very basic properties of bone substitute materials, though it has been shown that the dissolution products and the direct contact of cells to the material induce changes in cell metabolism and/or proliferation [10,58].

Whilst the indirect approach allows a detailed evaluation of the influence of the material's composition on the cells, direct culture settings also take the interaction of cells and material morphology into account [10,58]. Possible limitations for the use of direct culture settings are the high bioactivity of BGs that might lead to cell death and therefore requires careful pre-treatment of the used materials prior to contact with cells [41]. On the other hand, 3D culture settings in-vitro are challenging: Nutrition of cells, even in well-oxygenated surroundings, is only warranted by diffusion, which is a comparatively slow and insufficient type of nutrition compared to either dynamic, perfusion-based approaches or in-vivo settings with a focus on vascularization $[13,14,59]$. It was demonstrated that static 3D in-vitro culture settings are not sufficient to support stable cell populations, resulting in decreasing cell numbers-a limitation that was not yet described for indirect approaches $[13,58]$. Indirect cultivation of cells in presence of soluble parts of the materials under static conditions might therefore also help to assess the long-lasting differentiation characteristics of cells: Whilst the impact of the materials on cell proliferation and/or viability can be analyzed within a few days, osteogenic differentiation of cell populations takes weeks [60-62]. 


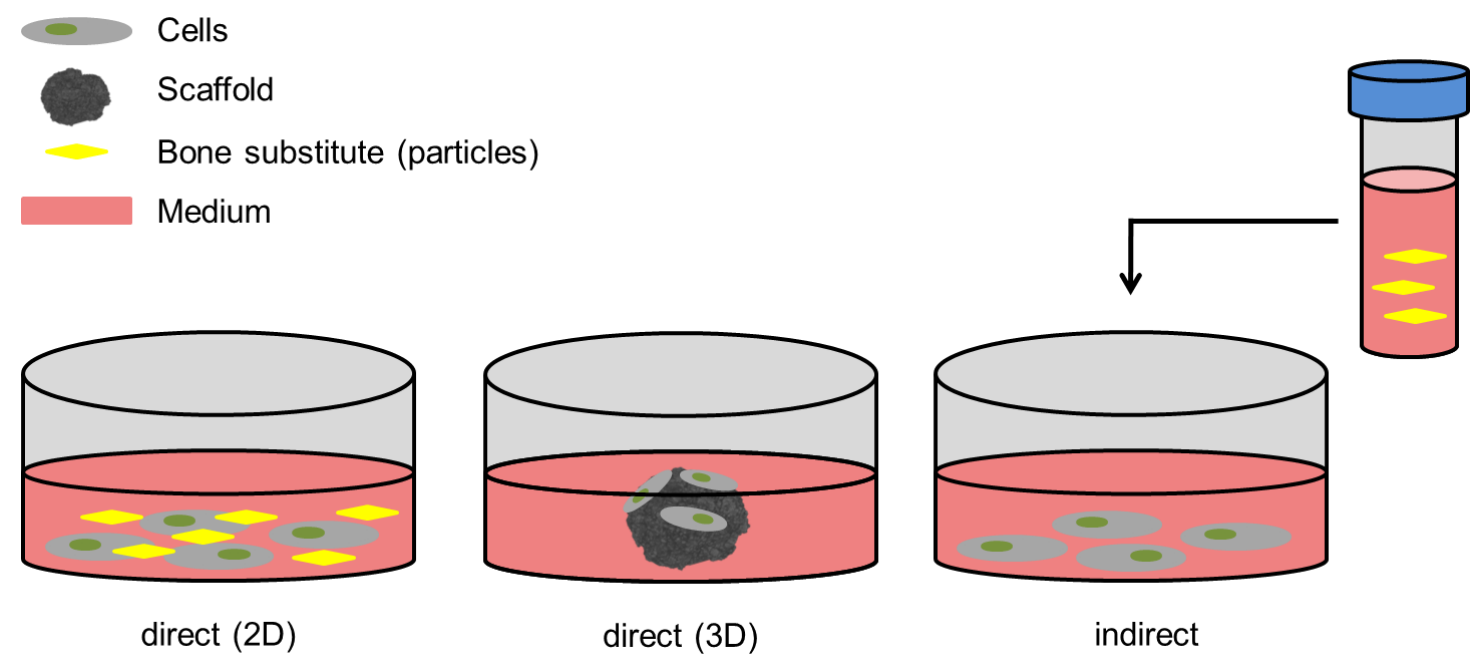

Figure 1. In-vitro evaluation models. 2D culture allows physical contact, mostly with particles of the respective bone substitute, whilst cells seeded on scaffolds are cultivated in 3D culture conditions. The indirect culture setting allows evaluation of the dissolution products of the materials that underwent incubation in the respective medium for a certain amount of time before the particle-free medium is transferred to the cells (indicated by the black arrow).

An example for "indirect" testing is the study of Chen et al.: Tests were performed with cells that were in indirect contact with the bone grafting material through "conditionized cell culture medium", which was produced by immersion of the grafting material in Dulbecco's modified eagle medium (DMEM) for $48 \mathrm{~h}$ [44]. Bellucci et al. used a combination of direct and indirect evaluation methods: Cell viability and proliferation were assessed indirectly, while the cells were also directly exposed to the material for the evaluation of the material's cytotoxicity; cell morphology was evaluated both after direct and indirect contact [19]. Although the authors described that there were no morphological differences between cells cultured in direct or indirect contact to the composite material, there is some evidence that the physical presence of materials (in this case BGs) has an impact on cell viability and proliferation, with a positive correlation of concentration and decreased cell vitality [58]. Therefore, the culture conditions have to be set carefully in order to meet the respective requirements and to specifically focus on the hypothesis of a study.

The cells used for the in-vitro assessment of bone grafting materials vary widely between the studies: Not only different cell types and cell numbers were used, but also cells originating from different species. In Table 2, the cell types, species, numbers, and culture settings are therefore summarized.

According to ISO-standards for biological evaluation of medical devices 10993-5, most of the studies (six of 10) used established cell lines to perform their assays [19,45,47,48,50,51]. Four studies used cells of primary cell cultures, which is feasible according to the ISO-standards if "[ ... ] reproducibility and accuracy of the response can be demonstrated" $[44,46,49,53]$. However, it was shown that the in-vitro studies used not only different cell culture settings but also different cell types of different species at different cell numbers that they incubated in different cell culture media, which means that practically every culture condition parameter differed between the studies. This complicates the interpretation of the studies and significantly reduces direct comparability. 
Table 2. In-vitro evaluation, study designs.

\begin{tabular}{|c|c|c|c|c|c|c|c|}
\hline $\begin{array}{c}\text { First } \\
\text { Author }\end{array}$ & Ref. & Cell Type & Species & Cell Number & Medium & $\begin{array}{l}\text { Culture } \\
\text { Time }\end{array}$ & $\begin{array}{l}\text { Culture } \\
\text { Setting }\end{array}$ \\
\hline Chen & {$[44]$} & $\mathrm{rMSC} / \mathrm{rOMSC}$ & rat & $100,000 / \mathrm{cm}^{2}$ & $\begin{array}{c}\mathrm{MM}+\text { Osteogenic } \\
\text { factors }(\beta-G P+A A)\end{array}$ & $21 \mathrm{~d}$ & indirect \\
\hline Lopes & {$[45]$} & MG 63 & human & $\begin{array}{l}\text { 8000/well } \\
\text { (96-well-plate) }\end{array}$ & MM & $3 \mathrm{~d}$ & direct \\
\hline Bellucci & [19] & $\begin{array}{l}\text { BALB/3T3 + } \\
\text { MLO-Y4 }\end{array}$ & mouse & $\mathrm{n} / \mathrm{s}$ & MM & $24 \mathrm{~h}-48 \mathrm{~h}$ & $\begin{array}{l}\text { direct and } \\
\text { indirect }\end{array}$ \\
\hline $\mathrm{Lu}$ & {$[46]$} & ASC & human & $\begin{array}{c}50,000 / 0.6 \mathrm{~cm}^{2} / \\
10,000 / 0.6 \mathrm{~cm}^{2}\end{array}$ & MM & $14 \mathrm{~d}$ & direct \\
\hline Bernhardt & [47] & SaOS-2 & human & $160,000 / 0.12 \mathrm{~cm}^{3}$ & $\begin{array}{c}\mathrm{MM}+\text { Osteogenic } \\
\text { factors }(\beta-G P+A A)\end{array}$ & $28 \mathrm{~d}$ & direct \\
\hline Bellucci & [48] & MC3T3-E1 & mouse & $50,000 / \mathrm{g}$ & $\begin{array}{c}\mathrm{GM}+\mathrm{ODM} \\
\text { (including } \beta-\mathrm{GP}+ \\
\mathrm{AA})\end{array}$ & $21 \mathrm{~d}$ & direct \\
\hline $\begin{array}{l}\text { Cholewa- } \\
\text { Kowalska }\end{array}$ & [49] & hBMSC & human & $10,000 / \mathrm{cm}^{2}$ & $\begin{array}{c}\mathrm{MM}+\mathrm{ODM} \\
\text { (including DM + } \\
\mathrm{AA} \text { ) }\end{array}$ & $7 \mathrm{~d}$ & direct \\
\hline Hesaraki & {$[50]$} & G-292 & human & $30,000 / \mathrm{mL}$ & MM & $7 \mathrm{~d}$ & direct \\
\hline Cai & {$[51]$} & MC3T3-E1 & mouse & $1,000,000 / 0.375 \mathrm{~cm}^{2}$ & MM & $14 \mathrm{~d}$ & direct \\
\hline Haimi & [53] & ASC & human & $500,000 / 0.98 \mathrm{~cm}^{2}$ & MM & $14 \mathrm{~d}$ & direct \\
\hline
\end{tabular}

n/s: not specified, rMSC: rat bone marrow-derived mesenchymal stem cells, rOMSC: osteoporotic rat bone marrow-derived mesenchymal stem cells, MG 63: osteoblast-like cells, BALB/3T3: mouse embryonic fibroblast cell line, MLO-Y4: murine long bone osteocyte-like immortalized cell line, ASC: adipose tissue-derived mesenchymal stem cells, SaOS-2: osteoblast-like cells, hBMSC: human bone marrow stromal cells, G-292: human osteosarcoma cells, MC3T3-E1: mouse osteoblast precursor cell line, MM: maintenance medium, GM: growth medium, ODM: osteogenic differentiation medium, $\beta$-GP: $\beta$-glycerophosphate, AA: ascorbic acid, DM: dexamethasone. The cell number per sample refers either to the surface of the scaffold / the well $\left(\mathrm{cells} / \mathrm{cm}^{2}\right)$ or to the scaffold without further specification (arbitrary unit) or the volume of the medium (cells $/ \mathrm{mL}$ ). Culture time in days (d) or hours (h). If multiple cell numbers are indicated, different cell numbers were used for different assays within one study.

\subsection{Analysis of Cell Morphology, Adhesion and Surface Interaction}

Cell morphology, adhesion on the scaffold and cell-surface-interaction were evaluated by scanning electron microscopy (SEM) in six studies [45-48,51,53], while Bellucci et al. evaluated cell morphology of cells having direct or indirect contact to bone grafting materials with conventional optical microscopy [19]. The assessments were performed at different time points serving different purposes: Cell attachment/adhesion was evaluated rather early in cell culture $[19,45-47,53]$ whereas cell growth, material-cell interaction and cell morphology was evaluated after 14 [51,53], 21 [48] or 28 days [47] of cell culture. Viable cells were detectable after seeding on scaffolds/incubating in medium that was in direct contact with the material in all studies which is an important prerequisite before performing further evaluations corresponding to the ISO-standards. Microscopy is a method for assessing cell well-being while offering an individual evaluation of materials and their particular interactions with cells. A disadvantage of microscopy is the difficulty of quantification of the results, rather allowing qualitative or semi-quantitative analyses. Still, evaluation of cell well-being during culture is crucial for performing further assays, especially cytotoxicity assays (ISO 10993-5).

\subsection{Analysis of Cell Viability, Cytotoxicity, and Proliferation}

The majority of the in-vitro studies (72\%) evaluated cell viability and metabolic activity quantitatively using colorimetric enzyme-dependent assays (e.g., the 3-(4,5-dimethylthiazol-2-yl)-2,5diphenyltetrazolium bromide (MTT) test) [19,44-50]. Every test consists of a substrate that is transformed into a colorimetrically detectable product by intracellular (mitochondrial) enzymes-the turnover (measured spectrophotometrically) correlates with the metabolic activity of the cells and with the number of viable cells [63]. Cell proliferation cannot be specifically derived from the colorimetric assays, so several additional methods were used to evaluate the proliferation: Bellucci et al. performed a bromodeoxyuridine-test [19], while Bernhardt et al. performed a dsDNA (double stranded deoxyribonucleic acid) quantification assay as well as the determination of lactate dehydrogenase (LDH) activity as proliferation marker for viable cells [47]. Others observed cell 
proliferation qualitatively by performing SEM of cell seeded scaffolds at two time points [46,47]. Cai et al. were the only group who evaluated only the proliferative capacity of the cells without monitoring their viability: They assessed cell proliferation by dislodging adherent cells from scaffolds and manually counting them in a blood cell counting chamber at three different time points [51]. Haimi et al. quantified the DNA content and performed a live/dead fluorescent cell staining at two different time points to determine cell proliferation both quantitatively and qualitatively as well as cell viability qualitatively through fluorescence microscopy [53]. The colorimetric assays allow to assess cytotoxicity of the material, as cytotoxic materials reduce cell number by causing cell death and diminishing metabolic activity of the surviving cells. Nevertheless, Bellucci et al. included an additional assay (Neutral Red Uptake Test (NRU)) to evaluate cell viability as a correlate to cytotoxicity of the material in direct contact to the cells [19]. Except for the studies of Cai et al. and Haimi et al. [51,53], every group performed an ISO-conform cytotoxicity test (meaning NRU, MTT, XTT (2,3-bis(2-methoxy-4-nitro-5-sulfophenyl)-5-[(phenylamino)carbonyl]-2H-tetrazolium hydroxide)), or a comparable test [48] to evaluate cytotoxic potential of the material. A particular protocol was used by Bellucci et al., who pre-incubated the cell-seeded scaffolds in growth medium for 15 days prior to incubating them in osteogenic differentiation medium [48]. Cell proliferation tests using the AlamarBlue Assay were performed after two, seven, and 14 days of incubation in osteogenic differentiation medium, resulting in a longer total incubation time of the cells on the scaffolds [48].

\subsection{Analysis of Osteogenic Differentiation}

Six of the 10 in-vitro studies assessed osteogenic differentiation, all by means of different methods, for example by measuring the activity of alkaline phosphatase (ALP) as a marker enzyme of osteoblasts correlating with the osteogenic differentiation of a cell population $[44,46-49,53]$. The evaluation of the activity of ALP is a valid method to measure osteogenic differentiation, as the enzyme is very active in osteoblastic cells; precursors of osteoblasts (preosteoblasts) can even be recognized by membrane-associated alkaline phosphatase markers in-vivo [64-67]. However, since the osseous alkaline phosphatase activity is rather unstable regarding temperature changes, assays need to be processed in highly standardized protocols to guarantee comparability of the results [68]. Nevertheless, determining ALP activity remains a gold standard parameter for osteogenic differentiation. Haimi et al. semi-quantitatively determined ALP activity by additionally performing a leukocyte ALP staining of the cell-seeded scaffolds, which visualizes that the photometrically detected activity originates from the ASC, as ALP is expressed in other cells as well [53,69].

In some studies, evaluation of ALP activity is combined with quantification of gene expression using quantitative real-time polymerase chain reaction analysis (qPCR) [44,46,47]. By quantifying the expression of osteogenic genes, osteogenic differentiation can be monitored in greater detail: Different genes are highly expressed at different maturation stages of osteoblastic cells [70]. A detailed observation of the cellular differentiation is therefore possible by using different combinations of early and late osteogenic genes [71]. The measurement of gene activity can be complemented by quantifying the expression of proteins that are encoded by the respective genes. For example, Chen et al. used an Enzyme-linked Immunosorbent Assay (ELISA) to quantify protein production [44]. Haimi et al. were the only group to perform an assay to measure the concentration of osteopontin, a specific protein crucial for bony development, without evaluating the corresponding gene expression [53].

As another correlate of osteogenic differentiation, cell populations that develop towards osteoblasts start to build a certain extracellular matrix that includes calcium deposits and therefore undergoes mineralization [44,60,61]. Alizarin Red S-staining is a method to evaluate mineralization in-vitro, however it needs to be interpreted carefully when used in 2D and 3D direct culture (thus in physical presence of CaPs and BGs): Especially when analyzing BGs that start building a HCA-layer in physiological solutions, the resulting calcium deposition might lead to false positive results even without osteogenic differentiation and matrix deposition of the surrounding cell population $[25,33,60,61,72]$. In the present study of Chen et al., Alizarin Red S-stained samples 
did not contain scaffolds, but cells in culture medium that was in direct contact with the material [44]. Therefore, the staining can be used as a valid method for evaluating mineralization [44,73-75].

\subsection{Cell Culture Media Used}

Although the cell culture media also differ between the studies, it is possible to classify two groups in dependency on the study objective: In six studies, maintenance medium without any factors stimulating osteogenic differentiation was used, focusing on cell proliferation and viability and trying to prove the absence of cell cytotoxicity induced by the respective material $[19,45,46,50,53,76]$, including rather short cultivation periods (median seven days, range from $24 \mathrm{~h}$ to 28 days). In four studies the cells were incubated in medium including factors promoting osteogenic differentiation [44,47-49]. These studies focused not only on cell proliferation and cytotoxicity of the material, but also on the osteoinductive potential of the material, meaning the osteogenic differentiation of the cells.

In two studies, $\beta$-glycerophosphate and ascorbic acid were added to the maintenance medium [44,47], while Cholewa-Kowalska et al. added ascorbic acid and dexamethasone [49]. It is known that dexamethasone, ascorbic acid, and $\beta$-glycerophosphate stimulate osteogenic differentiation in in-vitro settings by influencing different cellular pathways required for differentiation of mesenchymal stem cells (MSCs) to osteoblasts $[60,61,77]$. It is shown for dexamethasone that at least three weeks of continuous stimulation are necessary to reach full osteogenic differentiation, while only Bernhardt et al., Bellucci et al. and Chen et al. incubated for at least three weeks [44,47,48,78]. In the study of Cholewa-Kowalska et al., osteogenic differentiation medium was used, while the only assessed osteogenic differentiation marker was an ALP activity assay after seven days of cell culture [49]. Keeping the required stimulation time and continuity of osteogenic stimulation by dexamethasone in mind, it does not seem reasonable to evaluate osteogenic differentiation at a single time point after a short stimulation [79]. Cholewa-Kowalska additionally compared the cell number of samples incubated in maintenance medium (MM) to samples incubated in osteogenic differentiation medium (ODM) [49]. Bellucci et al. pre-incubated MC3T3-E1 cells in growth medium in order to allow proliferation before changing the medium by adding the osteostimulating factors $\beta$-glycerophosphate and ascorbic acid [48].

The other studies were using media without stimulating factors, aiming to show the osteostimulative capabilities of the material itself, as osteogenic stimulation factors are not necessary to evaluate cell survival and proliferation. The necessity and justification of the usage of osteogenic differentiation factors therefore depends on the assays that shall be performed-while their usage is justified in studies evaluating the osteogenic differentiation (e.g., by gene expression analysis), they are not required in studies assessing material properties such as cytotoxicity.

Lu et al. additionally compared the effect of pre-stimulation of the ASCs with BMP-2 on osteogenic differentiation to non-stimulated ASC, both cultured in growth medium [46]. They found that in the pre-stimulated group osteogenic differentiation (evaluated by means of qPCR and ALP activity) was significantly higher than in the unstimulated group, thus cells with two differentiation statuses were included in the study.

\section{In-Vivo Evaluation Models}

Out of the total number of 14 studies that were included into the review, in-vivo approaches were used in four studies (27\%). The respective in-vivo protocols are summarized in Table 3. No study used both in-vitro and in-vivo protocols. Three of these four in-vivo studies for the evaluation of bone graft composites used a New Zealand Rabbit animal model [18,51,52]. The group of Barbieri et al. used dogs as host organisms [43]. Every in-vivo study used an orthotopic design, thus the bone substitute material was implanted in bone defects. In the study of Barbieri et al., an ectopic intra-muscular implantation model was used additionally [43]. 
Table 3. In-vivo evaluation designs.

\begin{tabular}{|c|c|c|c|c|c|c|}
\hline First Author & Ref. & Species & $\begin{array}{l}\text { Location and } \\
\text { Defect Size }\end{array}$ & $\begin{array}{l}\text { Implantation } \\
\text { Time }\end{array}$ & Methods & Parameter \\
\hline \multirow{3}{*}{ Bellucci } & \multirow{3}{*}{ [18] } & \multirow{3}{*}{$\begin{array}{l}\text { New } \\
\text { Zealand } \\
\text { Rabbit }\end{array}$} & \multirow{3}{*}{$\begin{array}{l}\text { Femur } \\
\text { (3.5 mm diameter, } \\
7 \mathrm{~mm} \text { depth) }\end{array}$} & \multirow{3}{*}{$2 \mathrm{~m}$} & $\begin{array}{c}\text { Post-mortem femur } \\
\text { X-ray }\end{array}$ & Graft position \\
\hline & & & & & Histomorpho-metry & $\begin{array}{l}\text { Implant-bone-interface: bone } \\
\text { formation, bone } \\
\text { healing/contact, cracks of the } \\
\text { graft }\end{array}$ \\
\hline & & & & & $\begin{array}{c}\text { EDS + } \\
\text { microradiography }\end{array}$ & Dissolution kinetics \\
\hline Barbieri & [43] & Mongrel dog & $\begin{array}{l}\text { Orthotopic (spine) } \\
\text { and ectopic (i.m.) } \\
\text { (defect size } n / s \text { ) }\end{array}$ & $3 \mathrm{~m}$ & Histomorpho-metry & $\begin{array}{l}\text { Bone formation, } \\
\text { bone-surface-contact, in-vivo } \\
\text { resorption rate tissue response } \\
\text { (i.m.) }\end{array}$ \\
\hline \multirow{2}{*}{$\mathrm{Yu}$} & \multirow{2}{*}[51]{} & \multirow{2}{*}{$\begin{array}{l}\text { New } \\
\text { Zealand } \\
\text { Rabbit }\end{array}$} & \multirow{2}{*}{$\begin{array}{l}\text { Femur }(2 \mathrm{~mm} \\
\text { diameter, } \\
\text { depth } \mathrm{n} / \mathrm{s})\end{array}$} & \multirow{2}{*}{$1 / 2 / 3 / 6 \mathrm{~m}$} & Histomorpho-metry & $\begin{array}{l}\text { Bone formation, } \\
\text { bone-implant-interface, } \\
\text { resorption rates }\end{array}$ \\
\hline & & & & & SEM & $\begin{array}{l}\text { Bone formation, } \\
\text { bone-implant-interface, } \\
\text { resorption rates }\end{array}$ \\
\hline Kucukkolbasi & [52] & $\begin{array}{l}\text { New } \\
\text { Zealand } \\
\text { Rabbit }\end{array}$ & $\begin{array}{l}\text { Tibia (3 mm } \\
\text { diameter, } \\
\text { depth } \mathrm{n} / \mathrm{s})\end{array}$ & $1 / 3 / 6 \mathrm{~m}$ & Histomorpho-metry & $\begin{array}{l}\text { Bone formation, resorption } \\
\text { rates, tissue reactions }\end{array}$ \\
\hline
\end{tabular}

SEM: scanning electron microscopy, EDS: energy dispersion spectroscopy, HA: hydroxyapatite, i.m.: intramuscular. Implantation time in months $(\mathrm{m})$.

The implantation time varied among the studies in a range between one and six months, while two studies included multiple time points [51,52]. Each of the presented in-vivo settings included histomorphometrical analysis after explantation of the material with a focus on the analysis of parameters like bone formation, resorption rate, and contact between the implant and osseous tissue $[18,43,51,52]$. Barbieri et al. particularly focused on the surrounding tissue response (inflammation, soft tissue capsules and present cells) by implanting the material not only orthotopically into the bone but also in muscular pouches that were evaluated histologically [43]. To confirm and further detail the histologic results, Yu et al. and Bellucci et al. performed scanning electron microscopy (SEM), with a special focus on the cell-material interaction and surface alterations such as the formation of a HCA-layer (mentioned as bone-implant-interface or bone bonding mechanism) [18,51].

In the study of Bellucci et al., a post-mortem radiograph of the rabbit's femur was conducted in order to evaluate the position of the implanted bone graft materials, as well as an X-ray energy disperse spectroscopy (EDS) assay with the aim to assess the dissolution kinetics of the implant by detection of silicon ions that are specific for the used 45S5-BG [18].

Barbieri et al. further performed calcein labeling to evaluate bone development and growth over the time, as calcein deposits in growing bone after intravenous injection and is detectable through fluorescence microscopy $[43,80]$.

\section{Biological Properties of Composite Materials}

As mentioned above, high demands are placed on modern synthetic bone substitutes in order to reduce or even replace the usage of autologous bone graft material. Moore et al. therefore pointed out four crucial characteristics of such materials: osseointegration, osteoconduction, osteoinduction, and osteogenesis [81]. This basically means that the substitute should be able to bond to the surface of existing adjacent bone, to allow new bone to form on its surface, to induce differentiation of mesenchymal stem cells into cells of the osteoblastic lineage, and to let these osteoblasts form new bone on as well as within the material leading to step-by-step replacement of the substitute by newly 
formed host bone [81]. To complete this latter point, biodegradability should be added as a required feature. Degradation of bone substitutes occurs in form of dissolution as well as active cell-mediated resorption, mostly realized by osteoclasts $[82,83]$. Degradation is important not only in terms of replacement of foreign material by host tissue, but also the release of ions that are able to induce cell attachment, differentiation, and proliferation [16]. Both CaPs and BGs only partially fulfill these demands, especially when used separately [81].

The studies included in this meta-analysis either used in-vitro methods or in-vivo methods to assess the biological properties of the respective materials. Therefore, the following chapter is divided into an in-vitro and an in-vivo section and subdivided according to the methods used.

\subsection{Cell Vitality (In-Vitro)}

Looking at the included studies, cell vitality was the most investigated endpoint regarding biological properties, as 10 out of 14 studies analyzed it using different experimental approaches in-vitro. Cell vitality herein is meant as a collective term for viability, proliferation, number, and metabolic activity of cultured cells. Out of these 10 studies, seven directly compared CaP/BG composites to pure CaPs. Six of these studies revealed favorable results for CaP/BG composites [44,45,49-51]. They mostly used tetrazolium-based cell viability assays such as the MTT or the related 3-(4,5-dimethylthiazol-2-yl)-5-(3-carboxymethoxyphenyl)-2-(4-sulfophenyl)-2H-tetrazolium, inner salt (MTS) in order to determine the cell viability by measuring the metabolic activity of the cells. Under standardized conditions, one can also deduce the number of living cells in the sample. To give an example, Lopes et al. determined significantly higher amounts of cells on $\beta$-TCP scaffolds containing $7.5 \%$ 45S5-BG compared to those containing $5 \%$ or $0 \%$ using the MTT test, indicating that a higher amount of 45S5-BG supports the viability and proliferation of osteoblast-like cells [45]. This effect might be limited to a certain amount of 45S5-BG though. For instance, Bellucci et al. measured a continuous increase of cell quantity during cultivation time for their composite consisting of $20 \%$ 45S5-BG and 80\% HA, whereas the composite containing 40\% 45S5-BG and 60\% HA showed a slight initial decrease of total cells during the first week of culture, followed by an increase until day 14 [48]. This indicates that too high amounts of 45S5-BG lead to a certain cytotoxicity, at least initially, which was also described in recent literature [41]. Interestingly, the other BG used in this study (BG_Ca) induced a constant increase of cell number for both $20 \%$ and $40 \%$ composites [48]. The major difference between $45 \mathrm{~S} 5-\mathrm{BG}$ and BG_Ca is the alkali $\left(\mathrm{Na}_{2} \mathrm{O}\right)$ content $(24.5 \%$ vs. $4.6 \%)$. The presence of sodium ions might be a possible explanation for these differences, especially since the dissolution behavior of the materials seems to correspond to $\mathrm{pH}$ measurements [48]. According to additional in-vitro results, there is growing evidence that alkali-reduced or -free BGs might be superior regarding osteogenic properties when compared to 45S5-BG [84].

This given explanation can be supported by the findings of Cholewa-Kowalska et al. as well as Hesaraki et al., due to the fact that the BGs used in the mentioned studies did not contain $\mathrm{Na}_{2} \mathrm{O}$ at all but showed significantly better results in terms of cell viability for $\mathrm{CaP} / \mathrm{BG}$ compositions than for pure CaP [49,50]. While Cholewa-Kowalska et al. revealed the best results for 50\% BG composites [49], the percentage of BG $(10 \%, 25 \%$ and $40 \%)$ did not seem to have a major effect on cell proliferation in the study of Hesaraki et al. [50].

Conflictingly, Chen et al. used 45S5-BG at very high concentrations (93.3\% of the composite), yet showed the best results for this composite compared to pure CaP and pure BG [44]. It should be mentioned though that only indirect cultivation approaches were used in this study (Figure 1). After immersion of the materials in cell culture medium, the enriched medium was diluted with DMEM, at a ratio of $33 \%$ in this particular attempt [44]. Furthermore, it is known that the influence on cellular metabolism differs from indirect to direct culture settings [58]. Therefore, the high initial content of BG in this study cannot be directly compared to those in the other studies. Regarding cell proliferation, a direct approach may reflect reality slightly better compared to an indirect one, since in a bone defect cells are supposed to be viable and able to proliferate in direct proximity to the bone 
substitute material. Furthermore, they ideally should even migrate into the material and eventually build new bone there. Therefore, concerning proliferation, the direct approach-in this matter used in most of the mentioned studies-seems rather convenient, since results can be transferred more directly to the in-vivo or even the anticipated clinical situation.

Cai et al. determined proliferation by directly counting cells in a blood cell counting chamber, also measuring higher cell numbers on CaP/BG composites compared to pure CaP [51].

In another study, Bellucci et al. compared HA/BG_Ca/Mix scaffolds not to pure HA, but to pure 45S5-BG, revealing comparable and in some cases even better results for the composites [19]. Haimi et al. also did not detect remarkable differences in cell viability and proliferation when comparing composite materials to pure BGs or CaPs [53]. In the study of $\mathrm{Lu}$ et al. CaP/BG was not compared to any other material regarding cell viability [46]. Therefore, a clear statement whether composites or pure materials are advantageous cannot be made. However, MTS tests showed a threefold increase in cell number between day one and seven of cell culture [46].

Only Bernhardt et al. presented several disadvantages of composites in terms of cell viability. At best, $\mathrm{CaP} / \mathrm{BG}$ composites reached cell numbers comparable to those of pure $\beta$-TCP, falling behind with ongoing cultivation time [47].

Generally speaking, the rapid early dissolution of the BGs resulting in a major release of the ions correlating with excessive bioreactivity is a limitation for the use of BGs mainly in, but not limited to, in-vitro settings [41]. This rapid early release is often followed by an elevation of $\mathrm{pH}$ in the culture medium [48], inducing rather unfavorable conditions for cell cultivation [41]. However, a slightly alkaline surrounding favors the differentiation and activity of osteoblasts, whilst the function of osteoclasts, a cell type that is of certain relevance in the early phases of bone regeneration, is stimulated by slightly acidic surroundings [34-36]. There is limited evidence about the interaction of BGs with osteoclasts [83], but a dose-dependent enhancement of osteoclast differentiation was described in the presence of 45S5-BG [85]. By modulation of osteoclast activity, the degradation rate of mainly TCP-based composite materials might be modulated: Since TCP-based CaP-scaffolds tend to degrade (too) fast, adding BG in certain concentrations might slow down cellular degradation of the scaffold material $[16,83]$. However, further data analyzing the interactions of osteoclasts, osteoblasts, and $\mathrm{CaP} / \mathrm{BG}$ composites is required to understand the underlying mechanisms [83].

In summary, according to most of the surveyed studies (92\%), CaP/BG composites seem to have an advantageous or at least equal effect on in-vitro cell viability and proliferation compared to the respective materials alone.

\subsection{Osteogenic Differentiation (In-Vitro)}

Since CaP/BG composites are mainly designed for application in bone tissue engineering or bone regeneration, the influence of the material on osteogenic differentiation is an outcome parameter with great relevance. Therefore, in six studies either ALP activity assay, qPCR, RT-PCR, Alizarin Red S-staining, ALP staining or combinations of those were used $[44,46-49,53]$. In doing so, only Chen et al. realized an indirect approach since their focus lay on the addition of trace elements to the particular materials [44]. To give a counterexample, Bernhardt et al. focused more on the adhesion of cells, making direct approaches more suitable [47]. Four out of the six mentioned studies came to the conclusion that their particular composition of CaP and BG led to improved differentiation of MSCs or osteoblastic precursor cells towards osteoblasts [44,46,48,49]. All of these studies used assessment of ALP activity to determine osteogenic differentiation. In the studies of Chen et al., Lu et al., and Cholewa-Kowalska et al., compared to pure CaP increased ALP activity for CaP/BG composites within their individual periods of time were described [44,46,49]. Moreover, higher amounts of BG seemed to be advantageous compared to lower ones regarding ALP activity [49]. Bellucci et al. also reached higher levels of ALP activity for higher amounts of both BG_Ca and 45S5-BG within their composites, thereby excelling pure BGs [48]. 
Chen et al. and Lu et al. were also able to verify these results via qPCR by showing higher gene expression of osteogenic markers for composite groups than for pure CaP and BG respectively $[44,46]$. Examples for tested genes are ALP, Runx2 (Runt-related transcription factor 2), Col-I (collagen type I) and OPN (osteopontin), as well as other genes commonly associated with osteogenic differentiation $[44,46]$. Chen et al. even further confirmed their results on a "protein level", describing higher amounts of Runx2, Col-I and OC (osteocalcin) for the composite compared to pure CaP as well as pure BG [44].

At first sight, the study of Bernhardt et al. seems to describe contradictory findings concerning osteogenic differentiation: ALP activity in pure CaP was at least as high as or, depending on the point in time, even significantly higher than in CaP/BG [47]. Yet, a closer look reveals that the promising results of the other studies were often reached at BG percentages as high as $40 \%$ or even $50 \%[48,49]$, whereas Bernhardt et al. used a composition with only $4 \%$ BG [47]. For example, Cholewa-Kowalska et al. obtained similar values for pure $\mathrm{CaP}$, pure $\mathrm{BG}$ and $10 \%$ BG composites, but significantly higher values for composites containing 50\% BG [49]. This might reflect the need for a certain minimum content of BG that is necessary to alter the osteogenic properties of composite materials. At the same time, Bellucci and coworkers showed that composites might also outreach pure BGs [48], again indicating a certain suitable maximum of BG content.

However, Haimi et al. revealed no significant differences between pure BG and CaP-coated BG [53]. Interestingly though, osteopontin levels measured in the culture medium was significantly higher for samples with thin CaP-coating than for those with a thick coating [53]. This indicates that the amount of time a respective bone substitute material is preliminarily exposed to physiological conditions correlates with its osteoinduction and thus its biological properties. However, this may only occur due to the fact that under a thick layer of CaP the beneficial properties of the BG do not sufficiently affect the behavior of cultivated cells.

\subsection{Microscopy (In-Vitro)}

Another methodology often used in the included studies was conventional and/or scanning electron microscopy (SEM). These methods are often confined to rather qualitative statements, since standardization and technical feasibility can limit substantiated quantification. Nevertheless, microscopy often provides important impressions about basic mechanisms and might be used to qualitatively confirm statements acquired by other methods regarding plausibility. Three out of six studies that used microscopy in-vitro described promising results when using CaP/BG composites $[46,48,51]$, whereas the other half revealed no major difference between the compositions and pure $\mathrm{CaP}$ [47] or between composites with different amounts of BG or CaP respectively [19,53].

Lu et al., Cai et al. and Bellucci et al. all describe good cell adhesion and distribution on CaP/BG scaffolds by virtue of their SEM findings $[46,48,51]$. For example, Cai et al. revealed an almost continuous layer of osteoblasts on the $\beta$-TCP/BG mixture, whereas this observation was not made on pure $\beta$-TCP [51]. This indicates that phase composition is a crucial feature of bone substitute materials when it comes to cell adhesion, proliferation, and-as the desired consequence-new bone formation. It should be mentioned though, that different melting behavior during the fabrication of the scaffolds might lead to different microporosity and therefore different surface properties on the struts on a micron range [51]. These surface properties however are important characteristics of bone substitutes regarding cell adhesion, as osteoblasts and MSCs respectively prefer a rather rough surface $[16,48]$.

In contrast, according to Bernhardt et al. $\beta$-TCP and $\beta$-TCP/BG scaffolds showed no remarkable difference regarding cell adhesion [47]. Notably, they used 4\% BG in their composition, whereas Cai et al. and Bellucci et al. used $20 \%$ and up to $40 \%$ respectively [48,51]. This again leads to the implication that higher contents of BG may favor attachment, distribution, and-as already concluded above-viability, proliferation, and differentiation of cells. In another study, Bellucci et al. analyzed composites consisting of $30 \%$ as well as $80 \%$ BG with the appropriate amounts of HA, showing no major histomorphometric difference between these two concentrations [19]. Comparable results were 
revealed by Haimi et al., who showed no qualitative differences in cell morphology and proliferation on either pure BG and different CaP-coated BGs according to their SEM investigations [53]. Nevertheless, they described a sort of active contact between cells and BG, appearing as "cellular bridges" between BG particles [53].

Hence, although BG seems to support cell attachment and distribution, declaration of a suitable amount of BG for optimal in-vitro cell behavior seems to require further research.

\subsection{Microscopy (In-Vivo)}

As mentioned before, four out of 14 studies used in-vivo models. One major benefit, especially for bone defect models, is that these models provide a physiological surrounding for the bone substitute, so the model mimics the actual clinical situation of a bone defect [15]. Ossoeintegration, bone formation within the implant, and resorption kinetics can all be qualified and quantified by microscopy approaches. Although all four mentioned studies were conducting microscopy, they show rather heterogeneous results. Histomorphometry remains one of the most relevant methods in in-vivo studies for tissue discrimination and can even be used to quantify bone volume under certain conditions $[7,86]$. By specialized staining, such as antibody-based immunohistology or histochemical approaches, distinct properties that are affiliated with bone substitute materials can be assessed, for example the angiogenic potential [87]. Unfortunately, none of these approaches were used in either of the analyzed in-vivo studies.

Bellucci et al. described that according to histomorphometry, increased amounts of BG lead to increased osteoconduction, thus new bone formation and the ability of newly formed bone to attach to the surface of the implant [18]. In contrast to these findings, Barbieri et al. could hardly detect any newly formed bone on CaP/BG scaffolds, whereas bone formation on CaP scaffolds was better [43]. Notably though, the scaffolds investigated consisted not only of $\mathrm{CaP}$, but also of an AOC [43]. Since there was no control group represented by pure $\mathrm{CaP}$, it remains unclear whether bone formation was induced by $\mathrm{CaP}$ or AOC. For CaP/BG compositions, new bone formation could be detected only on neighboring host bone [43].

Kucukkolbasi et al. as well as $\mathrm{Yu}$ and coworkers did not mention distinct differences between pure $\mathrm{CaP}$ and $\mathrm{CaP} / \mathrm{BG}$ composites in terms of new bone formation or connective or marrow tissue [51,52]. Interestingly, the former of the two reported best results for a combination of HA, BG, and demineralized freeze-dried bone [52]. Considering the enormous plurality of possible additional composite materials, their further discussion would go beyond the scope of this review.

In summary, in-vivo investigations of bone substitute materials suggest that BG may support bone formation and healing under certain circumstances [18] as well as in presence of host bone [43]. Interestingly, the addition of further materials might also enhance the osteogenic properties of such materials [43,52].

\section{Conclusions}

BGs are known to stimulate osteogenic differentiation of precursor cell populations and are able to bond to surrounding tissues helping to integrate BG-based bone substitutes into bone, which is mediated by their surface reactivity. However, BGs suffer from poor mechanical properties when used as $3 \mathrm{D}$ bone substitutes. Furthermore, the local $\mathrm{pH}$-changes in the BG environment can be harmful to cells. CaPs, the most commonly used bone substitute materials, show good osteoconductive properties, but the material itself induces only limited stimulation of osteogenic differentiation and surface reactivity is comparably low. Not only the material properties but also the biological and osteogenic properties might be improved and the individual limitations of the materials might be overcome by combining CaPs and BGs, creating CaP/BG composite materials. In this review paper, the available data analyzing the biological properties of $\mathrm{CaP} / \mathrm{BG}$ composite materials and the impact of BG addition to the properties of CaPs was summarized and evaluated. Since the collective of studies analyzing the impact of BG on the biological properties of the materials was very heterogenous, direct comparison of 
the studies' results was not possible. However, when analyzing the studies individually, tendencies were detectable, especially in studies executing direct comparison of BG-supplemented and BG-free CaPs. In conclusion, BG-addition has positive effects on cell adhesion, viability, and proliferation compared to pure CaP materials. In-vivo, the presence of BG supports integration of the materials into bone as well as enhancing bone formation under certain circumstances. Future studies should analyze the effects of the composite materials on in-vivo resorption kinetics, since inappropriate degradation kinetics are a limitation of pure CaPs that can be tailored by addition of BGs. In order to do that, not only chemical but also cellular degradation should be assessed, meaning the interaction of BGs, CaPs, and CaP/BG composites with resorbing cells such as osteoclasts, which is not yet well understood. Direct comparison of the studies' outcomes was difficult due to the heterogeneous study designs. Therefore, upcoming studies should further commit to use comparable experimental setups in order to make inter-study interpretation of results feasible and to further support understanding of the biological properties of different CaP/BG composites.

Author Contributions: M.K., C.E. and F.W. are responsible for conceptualization, M.K., C.E. and S.T. conducted literature research, F.W., A.R.B and A.M. critically supervised and evaluated literature research, M.K., C.E., S.T., A.R.B, A.M. and F.W. wrote the paper, B.R. performed proofreading, all authors revised the paper critically, all authors approved the final version of the manuscript.

Funding: We acknowledge financial support by Deutsche Forschungsgemeinschaft within the funding program Open Access Publishing, by the Baden-Württemberg Ministry of Science, Research and the Arts and by Ruprecht-Karls-Universität Heidelberg.

Acknowledgments: Fabian Westhauser is supported by the "Physician Scientist Program"-scholarship introduced by the Medical Faculty of the University of Heidelberg.

Conflicts of Interest: The authors declare no conflict of interest.

\section{Abbreviations}

$2 \mathrm{D}$

$3 \mathrm{D}$

AA

ALP

AOC

ASC

BALB/3T3

BG

$\mathrm{CaP}$

Col-I

DM

DMEM

EDS

ELISA

G-292

GM

HA

hBMSC

HCA

i.m.

LDH

MC3T3-E1

MG 63

MLO-Y4

$\mathrm{MM}$

MSC

MTT two-dimensional

three-dimensional

ascorbic acid

alkaline phosphatase

alkylene oxide copolymer

adipose tissue-derived mesenchymal stem cells

mouse embryonic fibroblast cell line

bioactive glass

calcium phosphate

collagen type I

dexamethasone

Dulbecco's modified eagle medium

energy dispersion spectroscopy

Enzyme-linked Immunosorbent Assay

human osteosarcoma cells

growth medium

hydroxyapatite

human bone marrow stromal cells

hydroxyapatite-like

intramuscular

lactate dehydrogenase

mouse osteoblast precursor cell line

osteoblast-like cells

murine long bone osteocyte-like immortalized cell line

maintenance medium

mesenchymal stem cells

3-(4,5-dimethylthiazol-2-yl)-2,5-diphenyltetrazolium bromide 


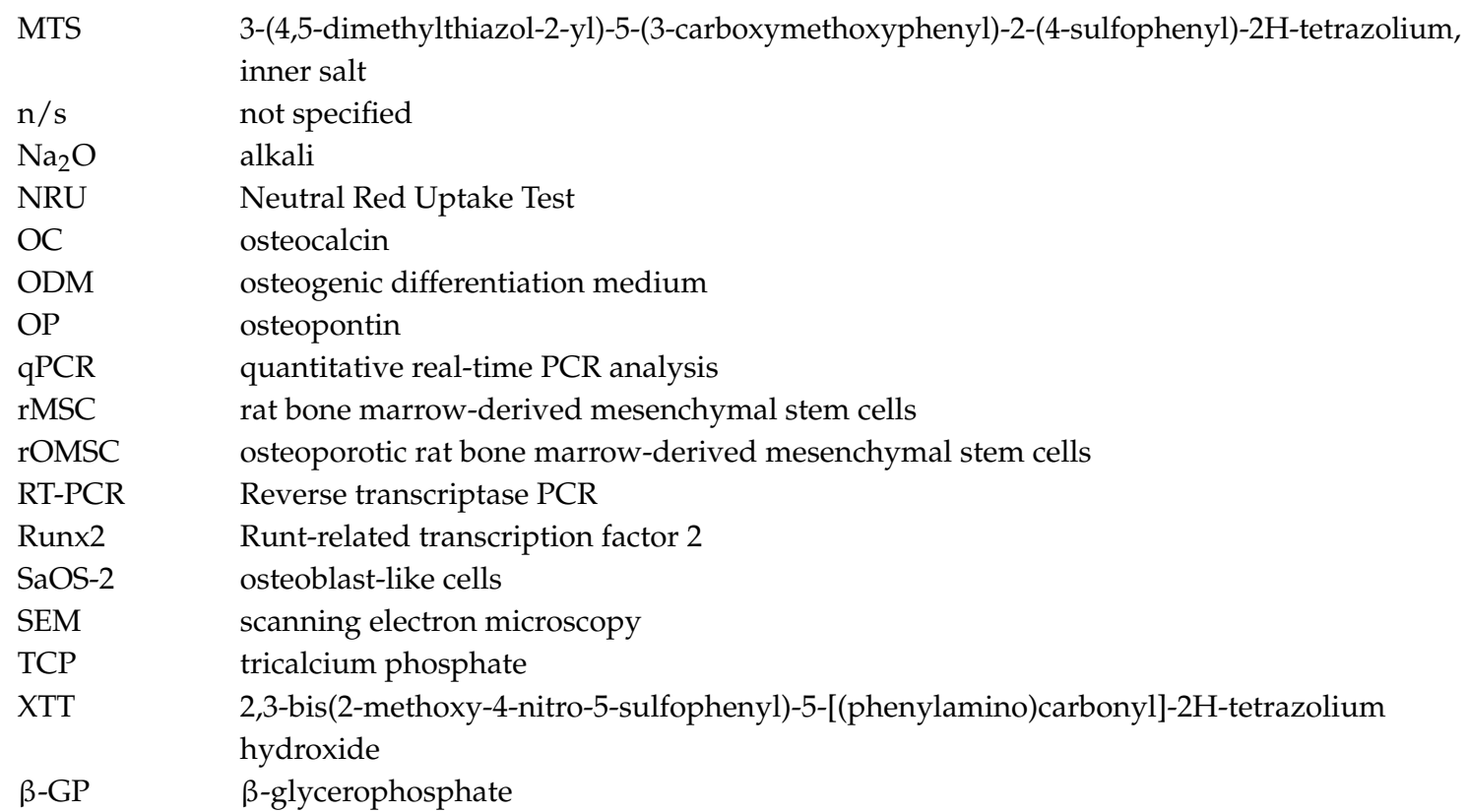

\section{References}

1. Wang, W.; Yeung, K.W.K. Bone grafts and biomaterials substitutes for bone defect repair: A review. Bioact. Mater. 2017, 2, 224-247. [CrossRef] [PubMed]

2. Giannoudis, P.V.; Einhorn, T.A.; Schmidmaier, G.; Marsh, D. The diamond concept-Open questions. Injury 2008, 39, S5-S8. [CrossRef]

3. Amini, A.R.; Laurencin, C.T.; Nukavarapu, S.P. Bone tissue engineering: Recent advances and challenges. Crit. Rev. Biomed. Eng. 2012, 40, 363-408. [CrossRef] [PubMed]

4. Dimitriou, R.; Mataliotakis, G.I.; Angoules, A.G.; Kanakaris, N.K.; Giannoudis, P.V. Complications following autologous bone graft harvesting from the iliac crest and using the RIA: A systematic review. Injury 2011, 42, S3-S15. [CrossRef] [PubMed]

5. Arrington, E.D.; Smith, W.J.; Chambers, H.G.; Bucknell, A.L.; Davino, N.A. Complications of iliac crest bone graft harvesting. Clin. Orthop. Relat. Res. 1996, 329, 300-309. [CrossRef]

6. Giannoudis, P.V.; Dinopoulos, H.; Tsiridis, E. Bone substitutes: An update. Injury 2005, 36, S20-S27. [CrossRef]

7. Westhauser, F.; Senger, A.S.; Reible, B.; Moghaddam, A. In Vivo Models for the Evaluation of the Osteogenic Potency of Bone Substitutes Seeded with Mesenchymal Stem Cells of Human Origin: A Concise Review. Tissue Eng. Part C Methods 2017, 23, 881-888. [CrossRef]

8. Zimmermann, G.; Moghaddam, A. Allograft bone matrix versus synthetic bone graft substitutes. Injury 2011, 42, S16-S21. [CrossRef]

9. Cao, W.; Hench, L.L. Bioactive materials. Ceram. Int. 1996, 22, 493-507. [CrossRef]

10. Hoppe, A.; Guldal, N.S.; Boccaccini, A.R. A review of the biological response to ionic dissolution products from bioactive glasses and glass-ceramics. Biomaterials 2011, 32, 2757-2774. [CrossRef]

11. Laskus, A.; Kolmas, J. Ionic Substitutions in Non-Apatitic Calcium Phosphates. Int. J. Mol. Sci. 2017, 18, 2542. [CrossRef]

12. Kolmas, J.; Velard, F.; Jaguszewska, A.; Lemaire, F.; Kerdjoudj, H.; Gangloff, S.C.; Kaflak, A. Substitution of strontium and boron into hydroxyapatite crystals: Effect on physicochemical properties and biocompatibility with human Wharton-Jelly stem cells. Mater. Sci. Eng. C 2017, 79, 638-646. [CrossRef] [PubMed]

13. Rath, S.N.; Strobel, L.A.; Arkudas, A.; Beier, J.P.; Maier, A.K.; Greil, P.; Horch, R.E.; Kneser, U. Osteoinduction and survival of osteoblasts and bone-marrow stromal cells in 3D biphasic calcium phosphate scaffolds under static and dynamic culture conditions. J. Cell Mol. Med. 2012, 16, 2350-2361. [CrossRef] [PubMed]

14. El-Rashidy, A.A.; Roether, J.A.; Harhaus, L.; Kneser, U.; Boccaccini, A.R. Regenerating bone with bioactive glass scaffolds: A review of in vivo studies in bone defect models. Acta Biomater. 2017, 62, 1-28. [CrossRef] [PubMed] 
15. Li, Y.; Chen, S.-K.; Li, L.; Qin, L.; Wang, X.-L.; Lai, Y.-X. Bone defect animal models for testing efficacy of bone substitute biomaterials. J. Orthop. Transl. 2015, 3, 95-104. [CrossRef] [PubMed]

16. Bellucci, D.; Sola, A.; Cannillo, V. Hydroxyapatite and tricalcium phosphate composites with bioactive glass as second phase: State of the art and current applications. J. Biomed. Mater. Res. A 2016, 104, 1030-1056. [CrossRef] [PubMed]

17. LeGeros, R.Z. Calcium phosphate-based osteoinductive materials. Chem. Rev. 2008, 108, 4742-4753. [CrossRef]

18. Bellucci, D.; Anesi, A.; Salvatori, R.; Chiarini, L.; Cannillo, V. A comparative in vivo evaluation of bioactive glasses and bioactive glass-based composites for bone tissue repair. Mater. Sci. Eng. C Mater. Biol. Appl. 2017, 79, 286-295. [CrossRef]

19. Bellucci, D.; Sola, A.; Anesi, A.; Salvatori, R.; Chiarini, L.; Cannillo, V. Bioactive glass/hydroxyapatite composites: Mechanical properties and biological evaluation. Mater. Sci. Eng. C Mater. Biol. Appl. 2015, 51, 196-205. [CrossRef]

20. Hannink, G.; Arts, J.J.C. Bioresorbability, porosity and mechanical strength of bone substitutes: What is optimal for bone regeneration? Injury 2011, 42, S22-S25. [CrossRef]

21. Hench, L.L.; Splinter, R.J.; Allen, W.C.; Greenlee, T.K. Bonding mechanisms at the interface of ceramic prosthetic materials. J. Biomed. Mater. Res. 1971, 5, 117-141. [CrossRef]

22. Balasubramanian, P.; Hupa, L.; Jokic, B.; Detsch, R.; Grünewald, A.; Boccaccini, A.R. Angiogenic potential of boron-containing bioactive glasses: In vitro study. J. Mater. Sci. 2017, 52, 8785-8792. [CrossRef]

23. Ojansivu, M.; Vanhatupa, S.; Bjorkvik, L.; Hakkanen, H.; Kellomaki, M.; Autio, R.; Ihalainen, J.A.; Hupa, L.; Miettinen, S. Bioactive glass ions as strong enhancers of osteogenic differentiation in human adipose stem cells. Acta Biomater. 2015, 21, 190-203. [CrossRef] [PubMed]

24. Gerhardt, L.C.; Boccaccini, A.R. Bioactive Glass and Glass-Ceramic Scaffolds for Bone Tissue Engineering. Materials 2010, 3, 3867-3910. [CrossRef]

25. Westhauser, F.; Ciraldo, F.; Balasubramanian, P.; Senger, A.S.; Schmidmaier, G.; Moghaddam, A.; Boccaccini, A.R. Micro-Computed-Tomography-Guided Analysis of In Vitro Structural Modifications in Two Types of $45 S 5$ Bioactive Glass Based Scaffolds. Materials 2017, 10, 1341. [CrossRef] [PubMed]

26. Hench, L.L.; Jones, J.R. Bioactive Glasses: Frontiers and Challenges. Front. Bioeng. Biotechnol. 2015, 3, 194. [CrossRef]

27. Chen, Q.Z.; Thompson, I.D.; Boccaccini, A.R. 45S5 Bioglass-derived glass-ceramic scaffolds for bone tissue engineering. Biomaterials 2006, 27, 2414-2425. [CrossRef] [PubMed]

28. Philippart, A.; Boccaccini, A.R.; Fleck, C.; Schubert, D.W.; Roether, J.A. Toughening and functionalization of bioactive ceramic and glass bone scaffolds by biopolymer coatings and infiltration: A review of the last 5 years. Expert Rev. Med. Devices 2015, 12, 93-111. [CrossRef]

29. Turnbull, G.; Clarke, J.; Picard, F.; Riches, P.; Jia, L.; Han, F.; Li, B.; Shu, W. 3D bioactive composite scaffolds for bone tissue engineering. Bioact. Mater. 2017, 3, 278-314. [CrossRef]

30. Clupper, D.C.; Hench, L.L. Crystallization kinetics of tape cast bioactive glass 45S5. J. Non-Cryst. Solids 2003, 318, 43-48. [CrossRef]

31. Boccaccini, A.R.; Chen, Q.; Lefebvre, L.; Gremillard, L.; Chevalier, J. Sintering, crystallisation and biodegradation behaviour of Bioglass ${ }^{\circledR}$-derived glass-ceramics. Faraday Discuss. 2007, 136, 27. [CrossRef] [PubMed]

32. Begum, S.; Johnson, W.E.; Worthington, T.; Martin, R.A. The influence of $\mathrm{pH}$ and fluid dynamics on the antibacterial efficacy of 45S5 Bioglass. Biomed. Mater. 2016, 11, 015006. [CrossRef] [PubMed]

33. Rahaman, M.N.; Day, D.E.; Bal, B.S.; Fu, Q.; Jung, S.B.; Bonewald, L.F.; Tomsia, A.P. Bioactive glass in tissue engineering. Acta Biomater. 2011, 7, 2355-2373. [CrossRef] [PubMed]

34. Kaysinger, K.K.; Ramp, W.K. Extracellular $\mathrm{pH}$ modulates the activity of cultured human osteoblasts. J. Cell Biochem. 1998, 68, 83-89. [CrossRef]

35. Arnett, T.R. Extracellular pH regulates bone cell function. J. Nutr. 2008, 138, 415S-418S. [CrossRef] [PubMed]

36. Galow, A.M.; Rebl, A.; Koczan, D.; Bonk, S.M.; Baumann, W.; Gimsa, J. Increased osteoblast viability at alkaline $\mathrm{pH}$ in vitro provides a new perspective on bone regeneration. Biochem. Biophys. Rep. 2017, 10, 17-25.

[CrossRef] [PubMed] 
37. Westhauser, F.; Weis, C.; Prokscha, M.; Bittrich, L.A.; Li, W.; Xiao, K.; Kneser, U.; Kauczor, H.U.; Schmidmaier, G.; Boccaccini, A.R.; et al. Three-dimensional polymer coated 45S5-type bioactive glass scaffolds seeded with human mesenchymal stem cells show bone formation in vivo. J. Mater. Sci. Mater. Med. 2016, 27, 119. [CrossRef] [PubMed]

38. Deschaseaux, F.; Sensébé, L.; Heymann, D. Mechanisms of bone repair and regeneration. Trends Mol. Med. 2009, 15, 417-429. [CrossRef]

39. Pryce, R.S.; Hench, L.L. Dissolution Characteristics of Bioactive Glasses. Key Eng. Mater. 2002, 240-242, 201-204. [CrossRef]

40. Detsch, R.; Alles, S.; Hum, J.; Westenberger, P.; Sieker, F.; Heusinger, D.; Kasper, C.; Boccaccini, A.R. Osteogenic differentiation of umbilical cord and adipose derived stem cells onto highly porous $45 \mathrm{~S} 5$ Bioglass ${ }^{\circledR}$-based scaffolds. J. Biomed. Mater. Res. Part A 2015, 103, 1029-1037. [CrossRef]

41. Ciraldo, F.E.; Boccardi, E.; Melli, V.; Westhauser, F.; Boccaccini, A.R. Tackling bioactive glass excessive in vitro bioreactivity: Preconditioning approaches for cell culture tests. Acta Biomater. 2018, 75, 3-10. [CrossRef] [PubMed]

42. Liberati, A.; Altman, D.G.; Tetzlaff, J.; Mulrow, C.; Gotzsche, P.C.; Ioannidis, J.P.; Clarke, M.; Devereaux, P.J.; Kleijnen, J.; Moher, D. The PRISMA statement for reporting systematic reviews and meta-analyses of studies that evaluate health care interventions: Explanation and elaboration. PLoS Med. 2009, 6, e1000100. [CrossRef]

43. Barbieri, D.; Yuan, H.; Ismailoglu, A.S.; de Bruijn, J.D. Comparison of Two Moldable Calcium Phosphate-Based Bone Graft Materials in a Noninstrumented Canine Interspinous Implantation Model. Tissue Eng. Part A 2017, 23, 1310-1320. [CrossRef] [PubMed]

44. Chen, X.Y.; Xu, S.Z.; Wang, X.W.; Yang, X.Y.; Ma, L.; Zhang, L.; Yang, G.J.; Yang, F.; Wang, L.H.; Zhang, X.L.; et al. Systematic comparison of biologically active foreign ions-codoped calcium phosphate microparticles on osteogenic differentiation in rat osteoporotic and normal mesenchymal stem cells. Oncotarget 2017, 8, 36578-36590. [CrossRef]

45. Lopes, J.H.; Magalhães, J.A.; Gouveia, R.F.; Bertran, C.A.; Motisuke, M.; Camargo, S.E.A.; Trichês, E.D.S. Hierarchical structures of $\beta$-TCP/45S5 bioglass hybrid scaffolds prepared by gelcasting. J. Mech. Behav. Biomed. Mater. 2016, 62, 10-23. [CrossRef] [PubMed]

46. Lu, Z.; Roohani-Esfahani, S.I.; Li, J.; Zreiqat, H. Synergistic effect of nanomaterials and BMP-2 signalling in inducing osteogenic differentiation of adipose tissue-derived mesenchymal stem cells. Nanomedicine 2015, 11, 219-228. [CrossRef] [PubMed]

47. Bernhardt, A.; Lode, A.; Peters, F.; Gelinsky, M. Comparative evaluation of different calcium phosphate-based bone graft granules-An in vitro study with osteoblast-like cells. Clin. Oral Implants Res. 2013, 24, 441-449. [CrossRef]

48. Bellucci, D.; Sola, A.; Gazzarri, M.; Chiellini, F.; Cannillo, V. A new hydroxyapatite-based biocomposite for bone replacement. Mater. Sci. Eng. C 2013, 33, 1091-1101. [CrossRef]

49. Cholewa-Kowalska, K.; Kokoszka, J.; Laczka, M.; Niedzwiedzki, L.; Madej, W.; Osyczka, A.M. Gel-derived bioglass as a compound of hydroxyapatite composites. Biomed. Mater. 2009, 4, 055007. [CrossRef]

50. Hesaraki, S.; Safari, M.; Shokrgozar, M.A. Composite bone substitute materials based on $\beta$-tricalcium phosphate and magnesium-containing sol-gel derived bioactive glass. J. Mater. Sci. Mater. Med. 2009, 20, 2011-2017. [CrossRef]

51. Yu, X.; Cai, S.; Xu, G.; Zhou, W.; Wang, D. Low temperature fabrication of high strength porous calcium phosphate and the evaluation of the osteoconductivity. J. Mater. Sci. Mater. Med. 2009, 20, 2025-2034. [CrossRef] [PubMed]

52. Kucukkolbasi, H.; Mutlu, N.; Isik, K.; Celik, I.; Oznurlu, Y. Histological evaluation of the effects of bioglass, hydroxyapatite, or demineralized freeze-dried bone, grafted alone or as composites, on the healing of tibial defects in rabbits. Saudi Med. J. 2009, 30, 329-333. [PubMed]

53. Haimi, S.; Moimas, L.; Pirhonen, E.; Lindroos, B.; Huhtala, H.; Raty, S.; Kuokkanen, H.; Sandor, G.K.; Miettinen, S.; Suuronen, R. Calcium phosphate surface treatment of bioactive glass causes a delay in early osteogenic differentiation of adipose stem cells. J. Biomed. Mater. Res. A 2009, 91, 540-547. [CrossRef] [PubMed]

54. Wiltfang, J.; Merten, H.A.; Schlegel, K.A.; Schultze-Mosgau, S.; Kloss, F.R.; Rupprecht, S.; Kessler, P. Degradation characteristics of alpha and beta tri-calcium-phosphate (TCP) in minipigs. J. Biomed. Mater. Res. 2002, 63, 115-121. [CrossRef] [PubMed] 
55. Baino, F.; Hamzehlou, S.; Kargozar, S. Bioactive Glasses: Where Are We and Where Are We Going? J. Funct. Biomater. 2018, 9, 25. [CrossRef] [PubMed]

56. Xin, R.; Leng, Y.; Chen, J.; Zhang, Q. A comparative study of calcium phosphate formation on bioceramics in vitro and in vivo. Biomaterials 2005, 26, 6477-6486. [CrossRef] [PubMed]

57. Jones, J.R. Review of bioactive glass: From Hench to hybrids. Acta Biomater. 2013, 9, 4457-4486. [CrossRef]

58. Qazi, T.H.; Hafeez, S.; Schmidt, J.; Duda, G.N.; Boccaccini, A.R.; Lippens, E. Comparison of the effects of $45 S 5$ and 1393 bioactive glass microparticles on hMSC behavior. J. Biomed. Mater. Res. A 2017, 105, 2772-2782. [CrossRef]

59. Leibig, N.; Wietbrock, J.O.; Bigdeli, A.K.; Horch, R.E.; Kremer, T.; Kneser, U.; Schmidt, V.J. Flow-Induced Axial Vascularization: The Arteriovenous Loop in Angiogenesis and Tissue Engineering. Plast. Reconstr. Surg. 2016, 138, 825-835. [CrossRef]

60. Reible, B.; Schmidmaier, G.; Prokscha, M.; Moghaddam, A.; Westhauser, F. Continuous stimulation with differentiation factors is necessary to enhance osteogenic differentiation of human mesenchymal stem cells in-vitro. Growth Factors 2017, 35, 179-188. [CrossRef]

61. Reible, B.; Schmidmaier, G.; Moghaddam, A.; Westhauser, F. Insulin-Like Growth Factor-1 as a Possible Alternative to Bone Morphogenetic Protein-7 to Induce Osteogenic Differentiation of Human Mesenchymal Stem Cells in Vitro. Int. J. Mol. Sci. 2018, 19, 1674. [CrossRef]

62. Pettersson, L.F.; Kingham, P.J.; Wiberg, M.; Kelk, P. In Vitro Osteogenic Differentiation of Human Mesenchymal Stem Cells from Jawbone Compared with Dental Tissue. Tissue Eng. Regen. Med. 2017, 14, 763-774. [CrossRef] [PubMed]

63. Carmichael, J.; DeGraff, W.G.; Gazdar, A.F.; Minna, J.D.; Mitchell, J.B. Evaluation of a tetrazolium-based semiautomated colorimetric assay: Assessment of chemosensitivity testing. Cancer Res. 1987, 47, 936-942. [PubMed]

64. Ashton, B.A.; Abdullah, F.; Cave, J.; Williamson, M.; Sykes, B.C.; Couch, M.; Poser, J.W. Characterization of cells with high alkaline phosphatase activity derived from human bone and marrow: Preliminary assessment of their osteogenicity. Bone 1985, 6, 313-319. [CrossRef]

65. Marie, P.J.; Lomri, A.; Sabbagh, A.; Basle, M. Culture and behavior of osteoblastic cells isolated from normal trabecular bone surfaces. In Vitro Cell. Dev. Biol. 1989, 25, 373-380. [CrossRef] [PubMed]

66. Koshihara, Y.; Kawamura, M.; Oda, H.; Higaki, S. In vitro calcification in human osteoblastic cell line derived from periosteum. Biochem. Biophys. Res. Commun. 1987, 145, 651-657. [CrossRef]

67. Beresford, J.N.; Gallagher, J.A.; Russell, R.G. 1,25-Dihydroxyvitamin D3 and human bone-derived cells in vitro: Effects on alkaline phosphatase, type I collagen and proliferation. Endocrinology 1986, 119, 1776-1785. [CrossRef]

68. Tan, I.-K.; Chio, L.-F.; Teow-Suah, L. Heat stability of human serum alkaline phosphatase in bone and liver diseases. Clin. Chim. Acta 1972, 41, 329-334. [CrossRef]

69. Hinnebusch, B.F.; Siddique, A.; Henderson, J.W.; Malo, M.S.; Zhang, W.; Athaide, C.P.; Abedrapo, M.A.; Chen, X.; Yang, V.W.; Hodin, R.A. Enterocyte differentiation marker intestinal alkaline phosphatase is a target gene of the gut-enriched Kruppel-like factor. Am. J. Physiol. Gastrointest. Liver Physiol. 2004, 286, G23-G30. [CrossRef]

70. Bonewald, L.F. The amazing osteocyte. J. Bone Miner. Res. 2011, 26, 229-238. [CrossRef]

71. Ragni, E.; Vigano, M.; Rebulla, P.; Giordano, R.; Lazzari, L. What is beyond a qRT-PCR study on mesenchymal stem cell differentiation properties: How to choose the most reliable housekeeping genes. J. Cell Mol. Med. 2013, 17, 168-180. [CrossRef] [PubMed]

72. El-Gendy, R.; Yang, X.B.; Newby, P.J.; Boccaccini, A.R.; Kirkham, J. Osteogenic differentiation of human dental pulp stromal cells on $45 \mathrm{~S} 5$ Bioglass $^{\circledR}$ based scaffolds in vitro and in vivo. Tissue Eng. Part A 2013, 19, 707-715. [CrossRef]

73. Lievremont, M.; Potus, J.; Guillou, B. Use of alizarin red S for histochemical staining of $\mathrm{Ca}^{2+}$ in the mouse; some parameters of the chemical reaction in vitro. Acta Anatom. 1982, 114, 268-280. [CrossRef]

74. Stanford, C.M.; Jacobson, P.A.; Eanes, E.D.; Lembke, L.A.; Midura, R.J. Rapidly forming apatitic mineral in an osteoblastic cell line (UMR 106-01 BSP). J. Biol. Chem. 1995, 270, 9420-9428. [CrossRef]

75. Puchtler, H.; Meloan, S.N.; Terry, M.S. On the history and mechanism of alizarin and alizarin red S stains for calcium. J. Histochem. Cytochem. 1969, 17, 110-124. [CrossRef] [PubMed] 
76. Cai, S.; Xu, G.H.; Yu, X.Z.; Zhang, W.J.; Xiao, Z.Y.; Yao, K.D. Fabrication and biological characteristics of $\beta$-tricalcium phosphate porous ceramic scaffolds reinforced with calcium phosphate glass. J. Mater. Sci. Mater. Med. 2009, 20, 351-358. [CrossRef] [PubMed]

77. Langenbach, F.; Handschel, J. Effects of dexamethasone, ascorbic acid and $\beta$-glycerophosphate on the osteogenic differentiation of stem cells in vitro. Stem Cell Res. Ther. 2013, 4, 117. [CrossRef]

78. Song, I.H.; Caplan, A.I.; Dennis, J.E. In vitro dexamethasone pretreatment enhances bone formation of human mesenchymal stem cells in vivo. J. Orthop. Res. 2009, 27, 916-921. [CrossRef]

79. Birmingham, E.; Niebur, G.L.; McHugh, P.E.; Shaw, G.; Barry, F.P.; McNamara, L.M. Osteogenic differentiation of mesenchymal stem cells is regulated by osteocyte and osteoblast cells in a simplified bone niche. Eur. Cell Mater. 2012, 23, 13-27. [CrossRef]

80. Hale, L.V.; Ma, Y.F.; Santerre, R.F. Semi-Quantitative Fluorescence Analysis of Calcein Binding as a Measurement of In Vitro Mineralization. Calcif. Tissue Int. 2000, 67, 80-84. [CrossRef]

81. Moore, W.R.; Graves, S.E.; Bain, G.I. Synthetic bone graft substitutes. ANZ J. Surg. 2001, 71, 8. [CrossRef]

82. Sheikh, Z.; Najeeb, S.; Khurshid, Z.; Verma, V.; Rashid, H.; Glogauer, M. Biodegradable Materials for Bone Repair and Tissue Engineering Applications. Materials 2015, 8, 5744-5794. [CrossRef] [PubMed]

83. Detsch, R.; Boccaccini, A.R. The role of osteoclasts in bone tissue engineering. J. Tissue Eng. Regen. Med. 2015, 9, 1133-1149. [CrossRef] [PubMed]

84. Brito, A.F.; Antunes, B.; Dos Santos, F.; Fernandes, H.R.; Ferreira, J.M.F. Osteogenic capacity of alkali-free bioactive glasses. In vitro studies. J. Biomed. Mater. Res. B Appl. Biomater. 2017, 105, 2360-2365. [CrossRef] [PubMed]

85. Detsch, R.; Rubner, M.; Strissel, P.L.; Mohn, D.; Strasser, E.; Stark, W.J.; Strick, R.; Boccaccini, A.R. Nanoscale bioactive glass activates osteoclastic differentiation of RAW 264.7 cells. Nanomedicine 2016, 11, 1093-1105. [CrossRef]

86. Westhauser, F.; Reible, B.; Hollig, M.; Heller, R.; Schmidmaier, G.; Moghaddam, A. Combining advantages: Direct correlation of two-dimensional microcomputed tomography datasets onto histomorphometric slides to quantify three-dimensional bone volume in scaffolds. J. Biomed. Mater. Res. A 2018, 106, 1812-1821. [CrossRef]

87. Steffens, L.; Wenger, A.; Stark, G.B.; Finkenzeller, G. In vivo engineering of a human vasculature for bone tissue engineering applications. J. Cell Mol. Med. 2009, 13, 3380-3386. [CrossRef] 